\title{
Assessing Social Skills of Children with Autism ${ }^{*}$
}

\author{
Şeyda DEMIR ${ }^{1}$
}

\begin{abstract}
The purpose of this study was to assess social skills of children with autism according to different variables (rater, gender, age, onset age of education, level of autism, diagnosis, having siblings) using the Autism Social Skills Profile Turkish Form (ASSPT). The method used was causal-comparative model. The data were gathered from the parents and teachers of 208 children with autism who were aged between six and 17. Analyses showed that the social skill scores of the study group significantly differed in terms of the rater, level of autism, and diagnosis but not in terms of gender, age, onset age of education, or having siblings. The findings of this study are discussed in terms of the current literature findings regarding social skills of children with autism.
\end{abstract}

Keywords: Autism, social skills, assessment, Autism Social Skills Profile.

\footnotetext{
This study was produced from the author's master's thesis which was advised by Prof. N. Bülbin Sucuoğlu at the Institute of Educational Sciences at Ankara University.

Ress. Assist., Şeyda Demir. Ankara University, Department of Special Education, Ankara, E-mail: sedemir@ankara.edu.tr
} 


\section{SUMMARY}

Purpose and significance: The purpose of this study was to examine the factors related to social skills of children with autism. Social skills levels of children with autism and whether their social skills differ according to different variables (rater, gender, age, onset age of education, level of autism, diagnosis, and having siblings) were examined.

Method: The research design used was the causal-comparative model in which whether social skills of the children with autism differ according to different variables was investigated. The study group consisted of 208 children with autism aged six to 17 who attended special education public schools in three Turkish cities (Ankara, Istanbul, and Izmir). Data were gathered using a Socio-Demographic Form and the Autism Social Skills Profile Turkish Form (ASSP-T) that were filled by parents and teachers of the children.

Results: Parents gave higher scores than teachers to their children with autism in the social reciprocity and social participation/avoidance subscales and total scale but they gave lower scores than teachers in detrimental social behaviors subscale. Moreover, the scores of children with autism did not differ significantly in terms of gender, age, onset age of education, and having siblings. However, their scores significantly differed in terms of their level of autism and diagnosis. Children with high functioning autism had higher scores than children with low functioning autism in the total scale as well as the social reciprocity, and social participation/avoidance sub-scales; however their scores did not differ in detrimental social behaviors subscale. Moreover, children with pervasive developmental disorder had higher scores than children with autism in social reciprocity sub-scale.

Discussion and Conclusions: Identifying factors affecting the social skills deficits of children with autism is important in developing effective and adequate intervention programs targeting these children. Therefore supporting the findings of this study by further identifying factors affecting social skills of children with autism and to take precautions for these factors are important. 


\title{
Otizmli Çocukların Sosyal Becerilerinin Değerlendirilmesi"
}

\author{
Şeyda DEMIR ${ }^{2}$
}

ÖZ. Bu araștırmanın amacı Otizm Sosyal Beceriler Profili Türkçe Formu'nu (OSBP-T) kullanarak otizmli çocukların sosyal becerilerinin farklı değişkenler (değerlendiren kişi, cinsiyet, yaş, eğitime başlama yaşı, otizmin derecesi, tanı, kardeșe sahip olma) açısından değerlendirilmesidir. Araștırmada nedensel-karşılaştırma yöntemi kullanılmıştır. Araştırmanın verileri altı-17 yaş arası 208 otizmli çocuğun anne-babası ve öğretmenlerinin OSBP-T'yi doldurması yoluyla toplanmıştır. Verilerin analizi sonucunda, araştırma grubundaki çocukların OSBP-T toplam puan ve alt ölçeklerinden aldıkları puanların değerlendiren kiși, otizmin derecesi ve tanılarına göre anlamlı düzeyde farklılaştığı cinsiyetlerine, yaşlarına, eğitime başlama yaşlarına ve kardeşe sahip olmaya göre ise farklılaşmadığı görülmüştür. Araştırma bulguları var olan alanyazın çerçevesinde tartışılmıştır.

Anahtar Kelimeler: Otizm, sosyal beceri, değerlendirme, Otizm Sosyal Beceriler Profili.

\footnotetext{
Bu çalışma, yazarın Ankara Üniversitesi Eğitim Bilimleri Enstitüsü’nde, Prof. Dr. N. Bülbin Sucuoğlu danışmanlığında tamamlamış olduğu yüksek lisans tez çalışmasından üretilmiştir.

2 Arş. Gör., Şeyda Demir. Ankara Üniversitesi, Özel Eğitim Bölümü, Ankara,

E-posta: sedemir@ankara.edu.tr
} 


\section{GİRIŞ}

Otizm, bireyin sözel ve sözel olmayan iletişimini, sosyal etkileşimini ve eğitimsel performansını önemli şekilde etkileyen gelişimsel bir yetersizliktir (Anderson, 2006). Belirtileri genellikle üç yaş öncesinde ortaya çıkmakta ve dil gelişimi, sosyal ilişki geliştirmede zorluklar ve tekrarlayıcı davranışlar olmak üzere üç alanda kendisini göstermektedir (Amerikan Psikiyatri Birliği, 2013). Otizm tanısının en önemli ölçütleri iletişim becerileri ile sosyal becerilerdeki sınırlılık olarak kabul edilmektedir. Kanner'in otizm terimini ilk kez kullandığı 1943 'ten beri iletişim becerileri ile sosyal becerilerdeki sınırlılıklar otizmli bireylerin tanılanmasında önemini korumaktadır (Amerikan Psikiyatri Birliği, 2013).

Sosyal beceriler bireyin diğerleriyle etkili bir şekilde etkileşime girmesini ve sosyal olarak uygun olmayan tepkilerden kaçınmasını sağlayan, sosyal yönden kabul edilebilir öğrenilmiş davranışlardır (Gresham ve Elliot, 1984). Otizmli çocukların sosyal becerileri normal gelişim gösteren akranları ile diğer özel gereksinimli akranlarından belirgin derecede farklılıklar göstermektedir (Weiss ve Harris, 2001). Bu çocuklar, zihinsel özelliklerinden bağımsız olarak kendilerine özgü sosyal beceri özellikleri olan çocuklar olarak kabul edilmektedirler (Yirmiya ve Sigman, 1991).

Sosyal beceri yetersizlikleri otizmin temel özelliklerinden biri olmakla birlikte bu becerilerin düzeyi ve kullanımı bazı faktörlere bağlı olarak değişmekte, araştırmacılar konuya ilişkin üç önemli faktörden söz etmektedirler: dil becerileri, zekâ düzeyi ve eğitim alıp almama (Howlin ve Goode, 1998). Bunlara ek olarak otizmli çocukların sosyal becerilerini etkileyen diğer değişkenler ise cinsiyet (McLennan, Lord ve Schopler, 1993; Volkmar, Szatmari ve Sparrow, 1993), yaş (Klin, Saulnier, Sparrow, Cicchetti, Volkmar ve Lord, 2007; McKinnon ve Krempa, 2002), problem davranışlar (Day, Horner ve O’Neill, 1994), eğitime başlama yaşı (Howlin ve Goode, 1998), otizmden etkilenme düzeyi ve eğitim ortamları (Fryxell ve Kennedy, 1995; Akt., Harrower ve Dunlap, 2001) ile kardeşin olup olmamas1 (Knott, Lewis ve Williams, 2007) olarak belirtilmektedir.

Otizmli çocukların sosyal becerileri, çocuğu iyi tanıyan kişilerce doğal ortamlardaki gözlemlere dayanarak doldurulması gibi avantajları nedeniyle sıklıkla dereceleme ölçekleri kullanılarak değerlendirilmektedir (Merrell, 2001). Anne-babaların, öğretmenlerin veya akranların listelenen sosyal davranışları puanlaması şeklinde uygulanan dereceleme ölçekleri, otizmli çocukların sosyal becerilerinin değerlendirilmesi, yetersizlikleri temel alan sosyal beceri öğretim programlarının hazırlanması ve uygulanan programların etkililiğinin değerlendirmesi amacıyla kullanılmaktadır. Sosyal becerilerin değerlendirilmesinde en yaygın olarak kullanılan ölçek Gresham ve Elliott (1990) tarafından geliştirilen Sosyal Beceri Dereceleme 
Sistemi'dir (SBDS) (Bellini, 2006; Frankel, Myatt ve Feinberg, 2007; Koning ve Magill-Evans, 2001; Macintosh ve Dissanayake, 2006; Ozonoff ve Miller, 1995). Özel gereksinimli olmayan bireylerin sosyal becerilerini değerlendirmek amacıyla geliştirilmiş olan SBDS otizmli çocukların yanı sıra diğer özel gereksinimli çocukların sosyal becerilerini de değerlendirmek amacıyla kullanılabilmektedir. Ancak, sosyal becerilere ilişkin özelliklerinin otizmli çocukları diğerlerinden ayırdığı ve bu bireylerin kendilerine özgü sosyal beceri yetersizlikleri olduğu düşüncesinden hareketle araştırmacılar, bu gruba özgü sosyal beceri yetersizliklerini belirlemek amaciyla yeni dereceleme ölçekleri geliştirmeye çalışmışlardır. Oldukça az sayıda olan bu araçlardan birisi Sosyal Yantlayıcılık Ölçeği'dir (SYÖ) (Social Responsiveness Scale-SRS; Constantino, Davis, Todd, Schindler, Gross, Brophy ve diğ., 2003). SYÖ, otizmli çocukların sosyal beceri yetersizliklerini değerlendirmekten ziyade otizm ile diğer psikiyatrik bozuklukları ayırt etmek, bir diğer deyişle, ayırıcı tanıyı kolaylaştırmak amacıyla geliştirilmiştir.

Bellini ve Hopf (2007) diğer dereceleme ölçeklerinin dezavantajlarını ortadan kaldırmak amaciyla Otizm Sosyal Beceriler Profili'ni (OSBP) (Autism Social Skills Profile-ASSP) geliştirmişlerdir. OSBP, SYÖ’ye kıyasla sosyal karşılıklılığa ilişkin daha fazla madde içermekte ve bu özelliği otizmli çocukların sosyal becerilerini daha ayrıntılı olarak değerlendirmeye imkân vermektedir. Ayrıca, çocukların iletişim özelliklerine ilişkin maddeler de içermesi nedeniyle diğer dereceleme ölçeklerinden önemli ölçüde farklılaşmaktadır. OSBP, otizmli çocukların sosyal beceri yetersizliklerini belirlemek, yetersizlikleri temel alan müdahale programları oluşturmak ve uygulanan müdahale programının etkililiğini ölçmek üzere kullanılabilmektedir. Ölçek ile sosyal karş1lıklılık ve iletişim başlatma becerilerinin yanı sıra kendini diğerlerinin yerine koyabilme ve sözel olmayan iletişim becerileri gibi yetersizliklere ilişkin de bilgiler elde edilebilmektedir.

Otizmli çocukların sosyal becerilerinin incelendiği bir araştırmada (Macintosh ve Dissanayake, 2006) yüksek işlevli ve Asperger Sendromlu çocukların sosyal becerilerinin, hem anne-baba hem öğretmen değerlendirmelerinden aldıkları puanlara göre, normal gelişim gösteren akranlarından daha az olduğu belirlenmiş, anne-babalar ile öğretmenlerin değerlendirmelerinin genel olarak orta derecede ilişkili olduğu bulunmuştur. Bir başka çalışmada Murray, Ruble, Willis ve Molloy (2009) anne-babalar ve öğretmenlerden otizmli çocukların sosyal becerilerini değerlendirmelerini istemişler; anne-babalarının etkileşim başlatmayla ilgili maddelerde, öğretmenlerin ise etkileşime tepkide bulunma ve etkileşim sürdürmeyle ilgili maddelerde çocuklara daha yüksek puanlar verdiklerini bulmuşlardır. Diğer bir çalışmada (Klin ve diğerleri, 2007) ise yüksek işlevli otizmli çocukların yaşlarının artmasıyla sosyal beceri yetersizliklerinin de arttığı belirlenmiştir. 
İlgili araştırmalara göz atıldığında Türkiye'de otizmli çocukların sosyal becerilerini farklı değişkenler açısından inceleyen çalışmaların sınırlı olduğu, bu çocukların sosyal becerilerinin araştırmacıların veya öğretmenlerin kendi geliştirdikleri değerlendirme araçları kullanılarak değerlendirildiği görülmektedir (örn., Balçık, 2010). Oysa, sosyal beceri yetersizliklerinin otizmin temel özelliklerinden biri olması ve bu becerilerin kullanımının bazı faktörlere bağlı olarak değişmesi nedeniyle, otizmli çocukların sosyal becerilerini etkileyen faktörlerin incelenmesinin hem uygulamacılara hem de araştırmacılara önemli bilgiler sunacağ düşünülmektedir. $\mathrm{Bu}$ nedenle, bu çalışmada otizmli çocukların sosyal becerilerini değerlendirmek ve sosyal becerilerinin çeşitli değişkenlere göre değişip değişmediğini incelemek amaçlanmıştır. Bu amaç çerçevesinde aşağıdaki sorulara yanıt aranmıştır: 1. Otizmli çocukların sosyal becerileri ne düzeydedir? 2. Otizmli çocukların sosyal becerileri farklı değişkenlere göre (değerlendiren kişi, cinsiyet, yaş, eğitime başlama yaşı, otizmin düzeyi, otizm spektrum bozuklukları içerisinden alınan tanı, kardeşe sahip olma) anlamlı şekilde farklılaşmakta mıdır?

\section{YÖNTEM}

\section{Araştırma Modeli}

$\mathrm{Bu}$ çalışma otizmli çocukların sosyal becerilerinin bazı değişkenlere göre değişip değişmediğini inceleyen bir nedensel-karşılaştırma araştırmasıdır. Nedensel-karşılaştırma araştırmaları, incelenmek istenen var olan bir duruma yol açan faktörleri, faktörlere etki eden değişkenleri veya belli bir değişken açısından farklılaşan grupları belirlemek için kullanılmaktadır (Büyüköztürk, Kılıç Çakmak, Akgün, Karadeniz ve Demirel, 2014). Bu çalışmada cinsiyet, eğitime başlama yaşı, otizmin derecesi, tanı ve kardeşe sahip olmanın otizmli çocukların sosyal beceri düzeyleri üzerinde etkisi olup olmadığının belirlenmesi amaçlandığından nedensel-karşılaştırma yönteminin kullanılmasına karar verilmiştir.

\section{Çalışma Grubu}

Araştırmanın çalışma grubu Ankara, İstanbul ve İzmir'de yer alan Milli Eğitim Bakanlığı'na bağlı Bağımlı ve Bağımsız Otistik Çocuklar Eğitim Merkezleri ve İş Eğitim Merkezleri, Özel Eğitim Okulları ve Özel Rehabilitasyon Merkezleri'nde eğitim almakta olan altı-17 yaş arası otizmli çocuklardan oluşmuştur. Toplamda 208 otizmli çocuğun anne-babası ve öğretmenleri OSBP-T'yi doldurmuşlardır. Çocuklar tanılarına göre iki gruba ayrılmıştır. Birinci grupta otizm tanısı alan çocuklar ikinci grupta ise 
Asperger Sendromu olan çocuklarla Başka Şekilde Tanımlanamayan (BTT) çocuklar yer almaktadır. İkinci gruptaki çocuklar bu çalışmada, sayılarının az olmas1 nedeniyle (Asperger Sendromu $n=1$, BTT $n=33$ ) bir grupta toplanmış ve yaygın gelişimsel bozukluğu olan çocuklar (YGB) olarak adlandırılmışlardır. Çalışma grubunda yer alan çocukların \%26'sının genel eğitim sınıflarına devam ettiği bir başka deyişle kaynaştırma eğitimi aldığ 1 görülmektedir. Genel eğitim sınıflarına giden çocuklar RAM'lar tarafından birden fazla yetersizliği olmayan, zihinsel yetersizlikleri de hafif veya orta düzeyde olan başka bir deyişle işlev düzeyi yüksek çocuklar olarak görülmektedir (Milli Eğitim Bakanlığı [MEB], 2000). Bu nedenle, bu çalışmada kaynaştırma eğitimi alan çocuklar (RAM'ın değerlendirilmesi sonucunda çocukların devam ettikleri eğitim ortamına göre) otizm derecesi açısından işlev düzeyi yüksek, kaynaştırma eğitimi almayan çocuklar ise işlev düzeyi düşük çocuklar olarak kabul edilmişlerdir. Çalışma grubunda yer alan çocukların cinsiyet, kaynaştırma uygulamaları çerçevesinde genel eğitim sınıflarına devam etme durumları ile yaş, eğitime başlama yaşı, tanı ve kardeşleri olup olmamasına göre dağılımları Tablo 1'de yer almaktadır.

Tablo 1. Çalışma grubundaki otizmli çocukların özellikleri

\begin{tabular}{llcc}
\hline Değişken & & Sayı & $\mathbf{\%}$ \\
\hline \multirow{2}{*}{ Cinsiyet } & Kız & 29 & 13,9 \\
& Erkek & 179 & 86,1 \\
\multirow{4}{*}{ Genel Eğitim Sınıflarına Devam Etme } & Devam Eden & 54 & 26,0 \\
& Devam Etmeyen & 152 & 73,0 \\
& Belirtilmemiş & 2 & 1,0 \\
Yaş & 6-12 yaş & 171 & 82,2 \\
\multirow{3}{*}{ Eğitime Başlama Yaşı } & 13-17 yaş & 37 & 17,8 \\
\multirow{2}{*}{ Tanı } & 3,5 yaşından önce & 95 & 45,67 \\
& 4 yaşından sonra & 94 & 45,19 \\
Kardeş & Otizm & 174 & 83,7 \\
& YGB & 34 & 16,3 \\
& Var & 150 & 72,11 \\
& Yok & 57 & 27,40 \\
\hline
\end{tabular}

\section{Veri Toplama Araçları}

1. Sosyo-Demografik Form (SDF). SDF, çalışma grubundaki çocukların sosyal becerilerine etki ettiği düşünülen değişkenlere (cinsiyet, yaş, tanı vb.) ilişkin bilgileri toplamak amacıyla araştırmacı tarafindan geliştirilmiştir. 
2. Otizm Sosyal Beceriler Profili-Türkçe Formu (OSBP-T). OSBP otizmli çocukların sosyal beceri yetersizliklerini belirlemek ve bu yetersizliklere uygun müdahale programlarının geliştirilmesini sağlamak amacıyla Bellini ve Hopf (2007) tarafından geliştirilmiştir. Ölçekte yer alan 45 madde 3 faktörde toplanmaktadır. Bu faktörler, sosyal karşılıklılık, sosyal katılım/kaçınma ve zarar verici sosyal davranışlardır. Sosyal karşılıklılık, sosyal etkileşimlerin aktif olarak sürdürülmesine ve bakış açısı alabilme becerilerine ilişkin maddelerden oluşmakta, sosyal katılım/kaçınma sosyal katılım ve katılımın sonlandırılmasını ifade eden maddeleri içermekte, zarar verici sosyal davranışlar ise doğrudan olumsuz akran ilişkilerine yol açan sosyal yönden uygun olmayan davranışları ifade eden maddelerden oluşmaktadır. Likert tipi dörtlü dereceleme (1: hiçbir zaman-4: her zaman) ile veri toplanan ölçekten alınan yüksek puan olumlu sosyal davranışlar ile sosyal işlevlerde yeterliliği, düşük puan ise sosyal işlevlerde yetersizliği göstermektedir. Ölçeğin geçerlik ve güvenirlik çalışmaları altı-17 yaş arası 340 Amerikalı çocuğun anne-babalarından toplanan verilerle gerçekleştirilmiştir. Ölçeğin iç geçerliliği Cronbach Alfa katsayısı hesaplanarak gerçekleştirilmiş toplam ölçek, sosyal karşılıklılık, sosyal katılım/kaçınma ve zarar verici sosyal davranışlar için Cronbach Alfa değerleri sırasıyla $\alpha=.92, .92, .89$ ve .84 olarak bulunmuştur. Ölçeğin test tekrar test güvenirliği toplam puan için $\mathrm{r}=.90$, alt ölçekler için ise sırasıyla $.89, .86$ ve .84 'tür.

OSBP'nin Türkçeye uyarlaması Demir (2009) tarafindan gerçekleştirilmiştir. Ölçek önce İngilizce ve Türkçeyi iyi derecede bilen üç uzman tarafindan bağımsız olarak Türkçeye çevrilmiş sonrasında farklı üç uzman Türkçeye çevrilen ölçeği tekrar İngilizceye çevirmiştir. İki uzman ölçeğin Türkçe ve İngilizce çevirilerini inceleyerek son düzeltmeleri gerçekleştirmişlerdir. Sonrasında ölçek otizmli altı-17 yaş arası 208 çocuğun anne-babası tarafindan doldurulmuştur. Anne-babalardan elde edilen veriler üzerinden ölçeğin geçerlik ve güvenirlik çalışmaları gerçekleştirilmiştir. Doğrulayıcı faktör analizinin OSBP'nin orijinal faktör yapısını doğrulamaması üzerine yapılan açımlayıcı faktör analizi yapılmış, OSBPT'de faktör yük değeri .30 ve altında olan maddeler ile birden fazla alt ölçekte yer alan maddeler ölçekten çıkarılmış, ölçeğin son hali 41 maddeden oluşmuştur. Ölçekte yer alan 41 maddenin orijinal ölçekteki gibi üç faktörde toplandığı belirlenmiş ve faktörler orijinal ölçeğin alt ölçekleriyle aynı şekilde adlandırılmıştır. Ölçeğin aynı zamanda tek faktörlü bir yapı ile de kullanılabileceği belirtilmiştir. Ölçeğin güvenirlik çalışması, Cronbach Alfa katsayısı hesaplanarak gerçekleştirilmiş ölçeğin iç tutarlığı toplam puan için 
$\alpha=.84$ bulunmuştur. Alt faktörlerin iç tutarlıllı̆ 1 ise sosyal karş1lıklılık için $\alpha=.91$, sosyal katılım/kaçınma için $\alpha=.91$ ve zarar verici sosyal davranışlar için $\alpha=.78$ 'dir. Ölçüt geçerliği, otizmli çocukların ölçekten aldıkları puan ortalamalarının zihin engelli çocukların ortalamalarıyla karşılaştırılması ile gerçekleştirilmiştir. Buna göre, ölçek zihin engelli çocuklar ile otizmli çocukları anlamlı düzeyde ayırt etmektedir (OSBP-T $U: 3199.00, p=.00$; sosyal karş1lıklılık $U: 3456.500, p=.00$; sosyal katılım/kaçınma $U: 2888.00$, $p=.00$; zarar verici sosyal davranışlar $U: 5364.00, p=.00$ ). Ayrıca ölçeğin benzer yapıları ölçen SBDS Ebeveyn Formu'ndan (EF) elde edilen puanlarla ilişkisine bakılmış, OSBP-T ile SBDS-EF ölçekleri toplam puanları arasında orta derecede ve anlamlı düzeyde ilişki olduğu bulunmuştur $(r=.69, p<.01)$.

\section{Veri Toplama Süreci}

Çalışmada öncelikle Ankara, İstanbul ve İzmir'de yer alan Milli Eğitim Bakanlığı'na bağlı otizmli çocukların devam ettikleri okulların yöneticileriyle görüşmeler yapılmıştır. Araştırmacı çalışmanın amacı ve ölçme araçları hakkında bilgi vermiş, idareciler ya da rehber öğretmenler aracılığıyla araçların öğretmenler ve anne-babalar tarafindan doldurulması istenmiştir. Eksik ve hatalı doldurulan araçlar çalışma kapsamı dışında bırakıldıktan sonra 208 çocuğun anne-baba ve öğretmenlerinden elde edilen veriler SPSS-22 paket programına girilerek analizler yapılmıştır.

Otizmli çocukların sosyal beceri düzeyleri belirlenirken OSBP-T ve alt ölçek puanlarının ortalama ve standart sapmaları hesaplanmıştır. Otizmli çocukların sosyal becerilerine etki eden değişkenlerle ilgili analizlerin gerçekleştirilmesi sürecinde ise, grupta her bağımsız değişkenle ilgili çocuk sayıları belirlenmiş ancak çocuk sayısının birbirine eşit olmadığı gruplar için büyük gruptan çocuk seçilmiştir. Bu süreçte, küçük gruptaki çocuk sayısı kadar büyük gruptan çocuk rastgele olarak seçilmiş ve seçilen çocukların temel değişkenler açısından (cinsiyet, eğitime başlama yaşı vb.) küçük gruba benzer özelliklere sahip olmasına dikkat edilmiştir. Sonrasında her iki gruptaki çocukların OSBP-T ve alt ölçeklerden aldıkları puanların normal dağ 11 mö gösterip göstermediğine, gruptaki çocuk sayısı 50'nin altındaysa Shapiro Wilk Testi, 50'nin üzerindeyse Kolmogorov Smirnov Testiyle bakılmıştır. İstatistikler $D$ değeri olarak verilmiş; araştırma grubundan toplanan veriler normal dağılım gösteriyorsa ilişkisiz örneklemler için t-testi, normal dağılım göstermiyorsa Mann Whitney U-testi ya da Wilcoxon İşaretli Sıralar testi kullanılmasına karar verilmiştir. 


\section{BULGULAR}

\section{Otizmli çocukların sosyal becerileri ne düzeydedir?}

Otizmli çocukların sosyal beceri düzeylerinin belirlenebilmesi için OSBP-T'den ve alt ölçeklerinden aldıkları puanların ortalamaları ve standart sapmaları hesaplanmış ve sonuçlar Tablo 2'de verilmiştir.

Tablo 2. OSBP, OSBP-T ve alt ölçeklerinden otizmli çocukların aldığı puan ortalamalart

\begin{tabular}{|c|c|c|c|c|c|}
\hline & $\mathrm{N}$ & Ortalama & $\begin{array}{l}\text { Standart } \\
\text { Sapma }\end{array}$ & $\begin{array}{l}\text { Minimum } \\
\text { Puan }\end{array}$ & $\begin{array}{l}\text { Maksimum } \\
\text { Puan }\end{array}$ \\
\hline OSBP-T & 208 & 88.35 & 13.01 & 41.00 & 164.00 \\
\hline $\begin{array}{l}\text { OSBP (Orijinal } \\
\text { Ölçekten Alınan } \\
\text { Puanlar) }\end{array}$ & 340 & 105.82 & 18.94 & 67.00 & 177.00 \\
\hline Sosyal Karşı1lıkl11lk & 208 & 25.91 & 7.89 & 15.00 & 60.00 \\
\hline $\begin{array}{l}\text { Sosyal } \\
\text { Katılım/Kaçınma }\end{array}$ & 208 & 26.67 & 7.56 & 14.00 & 56.00 \\
\hline $\begin{array}{l}\text { Zarar Verici Sosyal } \\
\text { Davranışlar }\end{array}$ & 208 & 35.75 & 5.66 & 12.00 & 48.00 \\
\hline
\end{tabular}

Tablo 2'de görüldüğü gibi otizmli çocukların OSBP-T'den aldıkları toplam puanların ortalamas1 88.35 , standart sapmaları ise 13.01 'dir. Buna göre Türk otizmli çocukların OSBP-T puanlarının orijinal ölçekten elde edilen puanlara göre düşük olduğu söylenebilir.

\section{Otizmli çocukların sosyal becerileri hangi değişkenlere göre} farklılaşmaktadır?

a) Değerlendiren kişi: Otizmli çocukların OSBP-T'den ve alt ölçeklerinden aldıkları puanların değerlendiren kişiye (anne-baba veya öğretmen) göre farklılaşıp farklılaşmadığına bakabilmek için çalışma grubunda yer alan ve hem anne-babaları hem de öğretmenleri tarafindan sosyal becerileri değerlendirilmiş olan 178 çocuktan elde edilen veriler üzerinden grupların sıra ortalamaları arasındaki farka bakılmıştır. Verilerin normal dağılım göstermemesi nedeniyle bu farkın olup olmadığı aynı grup için farklı kişilerden veri toplanması nedeniyle Wilcoxon İşaretli Sıralar testi ile (Baştürk, 2010) incelenmiştir (anne-babalar için OSBP-T $D(178)=.12$, $p=.00$, sosyal karş1lıklılık $D(178)=.12, \quad p>.05$; sosyal katılım $/$ kaçınma 
$D(178)=.06, p>.05$; zarar verici sosyal davranışlar $D(178)=.06, p>.05$; öğretmenler için OSBP-T $D(178)=.11, \quad p=.00$, sosyal karşılıklılık $D(178)=.16, p=.00$; sosyal katılım/kaçınma $D(178)=.10, p=.00$; zarar verici sosyal davranışlar $D(178)=.07, p<.05)$. Otizmli çocukların anne-babalarıyla ögretmenlerinden elde edilen OSBP-T toplam puanlarıla alt faktör puanları arasındaki farkın anlamlı olduğu görülmüştür. Buna göre, anne-babalar otizmli çocuklara sosyal karş1lıklılık (Medyan $[M d n]=25.00$ ), sosyal $\mathrm{kat} 1 \mathrm{lım} / \mathrm{kaçınma}(M d n=27.00)$ alt ölçeklerinden ve tüm ölçekten $(M d n=86.24)$ ögretmenlerine oranla (sosyal karş1lıkl1lı $M d n=21.78$, $Z=6.029, p=.00, r=.45$; sosyal katılım $/$ kaçınma $M d n=23.00, Z=4.191, p=.00$, $r=.31$; OSBP-T $M d n=83.00, Z=2.978, p=.02, r=.22$ ) daha yüksek puan vermektedirler. Ancak, anne-babalar zarar verici sosyal davranışlar alt ölçeğinde $(M d n=35.87)$ öğretmenlerine oranla $(M d n=37.00)$ daha düşük puan vermişlerdir $(Z=4.190, p=.00, r=.31)$.

b) Cinsiyet: Otizmli çocukların OSBP-T'den aldıkları puanların cinsiyetlerine göre farklılaşıp farklılaşmadığına bakabilmek için çalışma grubunda yer alan $29 \mathrm{k}$ ı ile çalışma grubundan gelişigüzel olarak seçilen 29 erkek çocuktan elde edilen veriler üzerinden toplam puan ve alt faktör puanları ortalamaları arasındaki fark, veriler normal dağılım göstermediği için Mann Whitney U-testiyle araştırılmıştır (kızlardan elde edilen verilerde OSBP-T $D(29)=.84, p<.01$; sosyal karşılıklılık $D(29)=.80, p=.00$; sosyal $\mathrm{katıl}$ ım $/$ kaçınma $D(29)=.90, p<.05$; erkeklerden elde edilen verilerde OSBPT $D(29)=.79, \quad p=.00 ;$ sosyal karş1lıkl1lı $D(29)=.83, p=.00$; sosyal $\mathrm{katıl}$ ım/kaçınma $D(29)=.95, p>.05)$. Zarar verici sosyal davranışlar alt faktörü içinse veriler normal dağılım gösterdiği için bağımsız örneklemler için t-testiyle bakılmıştır (kılar $D(29)=.97, p>.05$; erkekler $D(29)=.95$, $p>.05$ ). Otizmli k1z ve erkeklerin OSBP-T toplam puan (kızlar $M d n=84.91$, erkekler $M d n=86.23 ; \quad U=-.48, p>.05, r=.08$ ), sosyal karş1l1kl11ık (kızlar $M d n=22.00$, erkekler $M d n=25.00 ; \quad U=389.50, \quad p>.05, \quad r=.06$ ), sosyal katılım $/$ kaçınma (kızlar $M d n=25.00$, erkekler $M d n=26.00 ; U=420.50, p>.05$; $r=.00$ ) ve zarar verici sosyal davranışlar (kızlar $\bar{x}=36.03, s s=6.21$; erkekler $\bar{x}=37.18, s s=5.79 ; t[56]=.05, p>.05 ; d=.19, r=.09)$ alt ölçeklerinden aldıkları puanlar arasında anlamlı bir fark olmadığı görülmüştür. Buna göre cinsiyetin otizmli çocukların sosyal becerileri üzerinde etkili bir değişken olmadığı söylenebilir.

c) Yaş: Otizmli çocukların OSBP-T'den aldıkları puanların yaşlarına göre farklılaşıp farklılaşmadığına bakabilmek için çalışma grubundaki otizmli çocuklar, ilköğretim çağında olanlar (İO:6-12 yaş, $n=171$ ) ile ortaöğretim çağında olanlar (OO:13-17 yaş, $n=37$ ) olmak üzere iki gruba ayrılmıştır. Daha sonra, ilköğretim çağında olan çocuk sayısı fazla 
olduğundan bu gruptan ortaöğretim çağında olanların sayısı kadar çocuk seçilmiştir. Her iki gruptan elde edilen veriler üzerinden ortalamalar arasındaki fark, verileri normal dağılım göstermeyen OSBP-T (İO $D(37)=.93, p=.02 ;$ OO $D(37)=.88, p<.01$ ) ve sosyal karş11klılık (İO $D(37)=.94, p=.03$; OO $D(37)=.93, p<.05)$ için Mann Whitney U-testi ile araştırılmıştır. Sosyal katılım/kaçınma (İO $D(37)=.98, \quad p>.05 ; \quad$ OO $D(37)=.94, p>.05$ ) ve zarar verici sosyal davranışlar alt ölçekleri için (İO $D(37)=.97, \quad p>.05 ;$ OO $D(37)=.95, \quad p>.05)$ veriler normal dağılım gösterdiğinden ortalamalar arasındaki fark bağımsız örneklemler için ttestiyle incelenmiştir. OSBP-T toplam puanları (İO $M d n=86.00 ;$ OO $M d n=85.00 ; U=609.00, p>.05, r=.09$ ), sosyal karş1lıklılık (IOO $M d n=27.00$, OO $M d n=26.00 ; \quad U=682.00, p>.05, r=.00$ ), sosyal katılım $/$ kaçınma (İO $\bar{x}=26.66, s s=6.71$; OO $\bar{x}=26.24, s s=8.48 ; t(72)=1.396, p>.05, d=.06, r=.03)$, ve zarar verici sosyal davranışlar (IO $\bar{x}=36.15$, ss $=5.09$; OO $\bar{x}=34.31$, $s s=6.92 ; t(72)=6.524, p>.05, d=.31, r=.15)$ alt ölçeklerinden altı-12 yaş grubunun aldığı puanlar ile 13-17 yaş grubunun aldığ puanlar arasında anlamlı bir fark bulunmamıştır.

d) Eğitime başlama yaşı: Otizmli çocukların eğitime başlama yaşlarının gelişimleri üzerinde etkili bir faktör olması nedeniyle, çalışma grubu üç buçuk yaşından önce eğitime başlayanlar $(n=95)$ ve dört yaşından sonra eğitime başlayanlar $(n=94)$ olmak üzere iki gruba ayrılmıştır (Çalışma grubunda yaşı 3.5 ile 4 arasında olan çocuk yoktur). Daha sonra OSBP-T ve alt ölçeklerinden aldıkları puanların eğitime başlama yaşlarına göre farklılaşıp farklılaşmadığına bakılmıştır. Her iki grupta yer alan çocuklardan elde edilen veriler normal dağılım göstermediğinden toplam puan ve sosyal karş1ıklılık alt ölçeği için sıra ortalamaları arasındaki farka Mann Whitney U-testiyle bakılmıştır (OSBP-T için 3,5 yaş öncesi $D(95)=.10, p<.05 ; 4$ yaş sonrasi $D(94)=.15, p=.00$; sosyal karş1l1kl1lık için 3,5 yaş öncesi $D(95)=.11$, $p<.01 ; 4$ yaş sonrası $D(94)=.13, p=.00)$. Sosyal katılım $/$ kaçınma ve zarar verici sosyal davranışlar alt ölçekleri için ise veriler normal dağılım gösterdiğinden t-testi uygulanmıştır (sosyal katılım/kaçınma için 3,5 yaş öncesi $D(95)=.08, p>.05 ; 4$ yaş sonras $D(94)=.08, p>.05$; zarar verici sosyal davranışlar için 3,5 yaş öncesi $D(95)=.06, p>.05$; 4 yaş sonrası $D(94)=.09$, $p>.05)$. OSBP-T toplam puanları ve alt ölçeklerinden alınan puanlar arasında otizmli çocukların eğitime başlama yaşlarına göre anlamlı bir fark olmadığ 1 görülmüsstür (OSBP-T için 3.5 yaş öncesi $M d n=85.00$; 4 yaş sonrası $M d n=85.00 ; U=4473.00, p>.05, r=.00$; sosyal karş1l1klılık için 3.5 yaş öncesi $M d n=24.00 ; 4$ yaş sonras1 $M d n=24.00 ; U=4154.50, p>.05, r=.07$; sosyal $\mathrm{kat} 1 \mathrm{lım} / \mathrm{kaçınma} \mathrm{için} 3.5$ yaş öncesi $\bar{x}=26.60, s s=7.17 ; 4$ yaş sonras1 $\bar{x}=26.67, \mathrm{ss}=7.77 ; t[188]=.06, p>.05, d=.00$; zarar verici sosyal davranışlar için 3.5 yaş öncesi $\bar{x}=36.28$, ss $=5.05 ; 4$ yaş sonrası $\bar{x}=35.08, s s=6.17$; 
$t[188]=1.46, p>.05, d=.21)$. Buna göre çalışma grubunda yer alan otizmli çocukların sosyal beceri düzeyleri eğitime başlama yaşına göre değişmemektedir.

e) Otizmin derecesi: Otizmli çocukların OSBP-T'den aldıkları puanların otizmin derecesine göre farklılaşıp farklılaşmadığına bakabilmek için çalışma grubundaki çocuklar genel eğitim sınıflarına devam edenler $(n=54)$ ile sadece özel eğitim okulu ve özel eğitim sınıflarına edenler $(n=152)$ olarak iki gruba ayrılmıştır. Genel eğitim sınıflarına devam eden otizmli çocuklar, yüksek işlevli (Yİ) çocuklar olarak kabul edilmiş, özel eğitim okullarında eğitim alanlar ise düşük işlevli otizmli (Dİ) olarak gruplanmıştır. Düşük işlevli gruptan 54 kişi gelişigüzel olarak seçilerek OSBP-T puanlarının otizmin derecesine göre farklılaşıp farklılaşmadığına Yİ olanlarla Dİ olan çocuklardan elde edilen veriler analiz edilerek, toplam puan (Yİ $D(54)=.16, p<.01$; Dİ $D(54)=.19, p=.00$ ), sosyal karş1lıklılık (Yİ $D(54)=.18, p=.00$; Dİ $D(54)=.18, p=.00)$ ve sosyal katılım $/$ kaçınma alt ölçeği için (Yİ $D(54)=.11, p>.05$; Dİ $D(54)=.12, p<.05$ ) ortalamalar arasındaki farka Mann Whitney U-testi ile zarar verici sosyal davranışlar alt ölçeği (Yİ $D(54)=.09, p>.05$; Dİ $D(54)=.09, p>.05$ ) için ise t-testiyle bakılmıştır.

Yİ olan çocuklar ile Dİ olan çocukların OSBP-T toplam puanları (Yİ $M d n=93.00$; Dİ $M d n=83.33 ; U=744.50, p=.00, r=.42$ ), sosyal karş1lıklılık (Yİ $M d n=28.00 ; \quad$ Dİ $M d n=21.35 ; \quad U=731.50, \quad p=.00, \quad r=.43$ ), sosyal katılım/kaçınma (Yİ $M d n=30.00$; Dİ $M d n=24.50 ; U=779.00, p=.00, r=.40$ ) alt ölçeklerinden aldıkları puanlar arasında anlamlı bir fark olduğu görülmektedir. Zarar verici sosyal davranışlar (Yİ $\bar{x}=34.19$, $s s=4.95$, Dİ $\bar{x}=36.05, s s=5.70 ; t[106]=1.388, p>.05, d=.35, r=.17)$ alt ölçeğinden ise iki grubun aldıkları puanlar arasında anlamlı bir fark olmadığı görülmektedir. $\mathrm{Bu}$ bulgulara göre, yükssek işlevli olan ve genel eğitim sınıflarına devam eden çocukların hem toplam ölçek puanları hem de sosyal karşılıklılık ve sosyal katılım/kaçınma faktör puanları düşük işlevli olanlardan daha fazla, zarar verici sosyal davranışlar alt ölçeğinden aldıkları puanların ise birbirine yakın olduğu bulunmuştur.

f) Tanı: Otizmli çocukların OSBP-T'den aldıkları puanların tanılarına göre farklılaşıp farklılaşmadığına bakabilmek için çalışma grubunda yer alan çocuklar otizm tanısı almış olanlar $(n=174)$ ile yaygın gelişimsel bozukluk (YGB) tanısı almış olanlar ( $\mathrm{n}=34)$ olmak üzere ikiye ayrılmışlardır. Daha sonra, otizm tanısı almış olan gruptan 34 çocuk seçilmiş ve iki grupta yer alan çocukların OSBP-T ve alt ölçeklerinden aldıkları puanların birbirinden farklılaşıp farklılaşmadığına bakılmıştır. Buna göre, çocuklardan elde edilen veriler üzerinden toplam puan (otizm $D(34)=.96, p>.05$; YGB $D(34)=.98$, 
$p>.05$ ), sosyal katılım/kaçınma (otizm $D(34)=.96, p>.05$; YGB $D(34)=.95$, $p>.05$ ) ve zarar verici sosyal davranışlar alt ölçeği (otizm $D(34)=.97, p>.05$; YGB $D(34)=.96, p>.05)$ için veriler normal dağılım gösterdiğinden ortalamalar arasındaki farka bağımsız örneklemler için t-testiyle; sosyal karş11ıklılık alt ölçeği (otizm $D(34)=.91, p<.01$; YGB $D(34)=.93, p>.05)$ için ise veriler normal dağılım göstermediğinden sıra ortalamaları arasındaki farka Mann Whitney U-testiyle bakılmıştır. OSBP-T toplam puanları (otizm $\bar{x}=90.10, s s=11.85$, YGB $\bar{x}=95.48, s s=13.19 ; t[66]=.44, p>.05, d=.43$, $r=.21$ ), sosyal katılım $/$ kaçınma (otizm $\bar{x}=28.27, s s=6.66$, YGB $\bar{x}=30.28$, $s s=6.60 ; t[66]=.20, p>.05, d=.31, r=.15)$ ile zarar verici sosyal davranışlar (otizm $\bar{x}=35.32$, ss $=5.25$, YGB $\bar{x}=34.19$, ss $=4.53 ; t[66]=.89, p>.05, d=.23$, $r=.12$ ) alt ölçeklerinden otizm tanısı almış çocukların aldığı puanlar ile YGB tanısı almış çocukların aldığı puanlar arasında anlamlı bir fark olmadığ görülmüştür. İki grubun, sosyal karşıl1klılık alt ölçeği puanları karşılaş̧tırıldığında ise otizm tanılı çocuklar $(M d n=26.00)$ ile YGB tanılı çocukların $(M d n=28.00)$ aldıkları puanlar arasındaki farkın anlamlı olduğu YGB tanılı çocukların sosyal karşılıklılık puanlarının otizmli gruba göre daha yüksek olduğu belirlenmiştir, $U=409.00, p<.05, r=.25$.

g) Kardeşe sahip olma: Bu çalışmada son bağımsız değişken olarak otizmli çocukların OSBP-T ve alt ölçeklerinden aldıkları puanların kardeşe sahip olmaya göre farklılaşıp farklılaşmadığının belirlenmesi amaçlanmıştır. $\mathrm{Bu}$ nedenle, çalışma grubunda yer alan çocuklar kardeşi olmayanlar (Kardeşi Yok: KY, n=57) ile bir veya daha fazla kardeşi olanlar (Kardeşi Var: KV, $\mathrm{n}=150$ ) olmak üzere iki gruba ayrılmıştır. Bu iki grup arasında OSBP-T ve alt ölçeklerinden alınan puanların birbirinden farklılaşıp farklılaşmadığına bakabilmek için $\mathrm{KV}$ grubundan 57 kişi gelişigüzel olarak seçilmiş ve analizler gerçekleştirilmiştir. Analiz sonuçlarına göre toplam puan (KY $D(57)=.15, p<.01 ; \mathrm{KV} D(57)=.17, p=.00)$ ve sosyal karş1lıklılık (KY $D(57)=.15, p<.01 ; \mathrm{KV} \mathrm{D}(57)=.15, p<.01)$ için veriler normal dağılım göstermediğinden Mann Whitney U-testiyle; sosyal katılım/kaçınma (KY $D(57)=.09, p>.05 ; \mathrm{KV} D(57)=.11, p>.05)$ ve zarar verici sosyal davranışlar alt ölçeği (KY $D(57)=.07, p>.05 ; \mathrm{KV} D(57)=.06, p>.05)$ için ise veriler normal dağılım gösterdiğinden bağımsız örneklemler için t-testiyle bakılmıştır. Kardeşi olan ve olmayan otizmli çocukların OSBP-T toplam puanlar1 (KY $M d n=87.00 ; \mathrm{KV} M d n=85.00 ; U=1482.50, p>.05, r=.07$ ), sosyal karşılıklılık (KY $M d n=25.00 ; \mathrm{KV} M d n=24.00 ; U=1606.50, p>.05$, $r=.01$ ), sosyal katılım/kaçınma (KY $\bar{x}=26.12, s s=6.61, \mathrm{KV} \quad \bar{x}=26.19$, $s s=7.86 ; t[112]=1.09, p>.05, d=.10, r=.05)$ ve zarar verici sosyal davranışlar $(\mathrm{KY} \bar{x}=36.37, s s=5.33, \mathrm{KV} \bar{x}=35.54, s s=5.96 ; \mathrm{t}[112]=1.22, p>.05, d=.15$, $r=.07)$ alt ölçeklerinden aldığı puanlar arasında anlamlı farklılıklar olmadığ 1 görülmüştür. 


\section{TARTIŞMA}

$\mathrm{Bu}$ çalışmada altı-17 yaş otizmli çocukların sosyal becerilerinin farklı değişkenler açısından incelenmesi amaçlanmıştır. Öncelikle, otizmli çocukların sosyal becerilerinin ne düzeyde olduğu belirlenmiş, sonra OSBP$\mathrm{T}$ toplam ve alt ölçek puanlarının değerlendiren kişiye (anne-baba ya da öğretmen), cinsiyete, yaşa, eğitime başlama yaşına, otizmin derecesine, tanılarına ve kardeşe sahip olmaya göre farklılaşıp farklılaşmadığına bakılmıştır.

Otizmli çocukların sosyal beceri düzeylerini incelediğimizde çalışma grubunun OSBP-T'den aldıkları puanların ortalamasının $88.35(s s=7.89)$ olduğu görülmektedir. Ölçekten alınabilecek en yüksek puanın 164.00, en düşük puanın ise 41.00 olduğu düşünüldüğünde, bu çalışma grubunun sosyal beceri düzeylerinin OSBP-T'ye göre düşük olduğu söylenebilir. Ayrıca araştırma grubu çocuklarının, benzer grupla çalışan Bellini ve Hopf'un (2007) deneklerinden $(\bar{x}=105.82, s s=18.94)$ daha düşük puanlar aldıkları görülmüştür. Bellini ve Hopf'un çalışmasında veri toplanan grubun \%68'inin yüksek işlevli çocuklardan oluşmasının, OSBP puan ortalamalarının yüksek olmasını açıkladığı düşünülebilir. Bu araştırmada ise çalışma grubunun \%26'sı, RAM'lar tarafından işlev düzeyleri temel alınarak yüksek işlevli olarak kabul edilip genel eğitim sınıflarına yerleştirilen çocuklardan oluşmuştur. Bu nedenle Amerikalı ve Türk çocuklarının OSBP'den aldıkları puanlar arasındaki farkın kültürel nedenlerden çok, araştırma grubunu oluşturan çocukların özelliklerine bağlı olarak ortaya çıktığı düşünülmektedir.

Otizmli çocukların anne-babaları OSBP-T toplam puan, sosyal karş1ıklılık, sosyal katılım/kaçınma alt ölçeklerine öğretmenlere oranla otizmli çocuklara daha yüksek, ancak zarar verici sosyal davranışlar alt ölçeğinde öğretmenlere göre daha düşük puan vermişlerdir. Alanyazın incelendiğinde birkaç çalışma dışında (Fantuzzo, Coolahan, Mendez, McDermott ve Sutton-Smith, 1998; Szatmari, Archer, Fisman ve Streiner, 1994), genellikle bu çalışmanın bulgularına benzer bulgular elde edildiğ görülmüştür. Diğer bir deyişle, alanyazında anne-babalar ile öğretmenlerin çocukların sosyal becerilerini değerlendirmeleri arasındaki tutarlılığın düşük olduğu sonucu daha fazla kabul görmektedir (Fagan ve Fantuzzo, 1999; Glover-Gagnon, Nagle ve Nickerson, 2007; Hinshaw, Han, Erhardt ve Huber, 1992; Manz, Fantuzzo ve McDermott, 1999; Randazzo, Landsverk ve Ganger, 2003; Winsler ve Wallace, 2002). Ancak, alanyazında değerlendirme sonuçları arasındaki farklılıklara karşın her iki kaynaktan da bilgi toplamanın çok önemli olduğu, anne-babalar ile öğretmenlerin 
çocuklara ilişkin çok önemli bir bakış açısı sundukları sıklıkla vurgulanmaktadır (Achenbach ve diğ., 1987; Akt., Hinshaw ve diğ., 1992). $\mathrm{Bu}$ gerekçeden yola çıkılarak, bu araştırmada her iki kaynaktan veri toplanmıştır. Anne-babalarla öğretmenlerden elde edilen veriler arasındaki bu farklılıklar çeşitli nedenlerle ortaya çıkabilmektedir (Glover-Gagnon ve diğ., 2007): a) anne-babalar çocukları farklı ortamlarda gözlediğinden davranışlara ilişkin yargıları da farklı olabilmektedir, b) anne-babalarla öğretmenlerin çeşitli davranışlara olan hoşgörüleri farklı olabilmektedir, c) anne-babalar sadece bir çocuk için değerlendirme yaparken, öğretmenler birçok çocuğu değerlendirdikleri için puanlamaları yorgunluk ve önyargıdan etkilenebilmektedir ve d) öğretmenler çocukları akranlarıyla karşılaştırarak değerlendirmekte, anne-babalar ise kendi çocuklarını farklı çocuklarla birlikte çok fazla gözleyememektedirler.

$\mathrm{Bu}$ çalışmada, değerlendirme yapan kişiye ek olarak otizmli çocukların sosyal becerileri üzerinde etkili olduğu düşünülen cinsiyet, yaş, eğitime başlama yaşı, otizmin derecesi, tanı ve kardeşe sahip olmanın OSBP-T ve alt ölçek puanlarında farklılaşmaya yol açıp açmadığı da incelenmiştir. $\mathrm{Bu}$ değişkenlerden cinsiyet, yaş, eğitime başlama yaşı ile kardeşe sahip olmanın OSBP-T ve alt ölçek puanları üzerinde etkili olmadığı, ancak otizmin derecesi ve çocuğun tanısının etkili olduğu bulunmuştur.

Otizmli çocukların sosyal becerilerini inceleyen çalışmalarda cinsiyete ilişkin çelişkili sonuçlar yer almaktadır. Bazı araştırmacılar erkeklerin sosyal becerilerinin kızlardan daha yetersiz olduğunu ortaya koyarken (McLennan ve diğ., 1993; Skuse ve diğ., 2009) bazı araştırmacılar kızlarla erkekler arasında farklılıklar olmadığını gösteren bulgulara ulaşmışlardır (Bellini ve Hopf, 2007; Winsler ve Wallace, 2002). Bu çalışmada ise OSBP'yi geliştiren Bellini ve Hopf'un da çalışmasında olduğu gibi çocukların cinsiyetinin OSBP puanlarını etkilemediği ortaya konmuştur.

Alanyazında otizmli çocukların ergenliğe girdiklerinde sosyal beceri yetersizliklerinin arttığının belirtilmesine karşın (Klin ve diğ., 2007) bu araştırmada yaşı artmasıyla birlikte sosyal beceri yetersizliklerinde anlamlı bir artış olmadığ 1 belirlenmiştir. Bellini ve Hopf (2007) çalışma grubunun çoğunluğunu yüksek işlevli çocukların oluşturduğu araştırmalarında, altı-11 ve 12-17 yaş grupları arasında OSBP'den alınan puanlar açısından anlamlı fark olmadığını belirtmişlerdir. Yaş grupları arasındaki farklara ilişkin bu bulguların ileri çalışmalarda da yinelenmesinin önemli olduğu düşünülmektedir.

Alanyazında yapılan araştırmalarda eğitimden alınan en iyi sonuçların çok erken yaşta eğitime başladığında elde edildiği vurgulanmakta (Scheinkopf ve Siegel, 1998), eğitime başlama yaşı ne kadar erken olursa 
çocukların gelişimsel kazançlarının da o kadar artacağ ${ }_{1}$ savunulmaktadır (Rogers, 1998). Bu çalışmada ise eğitime başlama yaşının sosyal beceriler üzerinde etkili bir değişken olmadığı bulunmuştur. Bu bulgunun erken eğitimle otizmli çocukların bilişsel becerilerinin gelişmesine karşın sosyal becerilerinin daha az gelişmesinden kaynaklandığı düşünülebilir (Green, 1996). Buna ek olarak Türkiye'de otizmli çocuklar için uygulanan programlar incelendiğinde (http://orgm.meb.gov.tr/), sosyal becerilerin her yaş grubu için belirlenen öğretimsel amaçlar arasında çok az yer aldığı, öğretimin özellikle kavram, akademik becerilerin öğretimi ile dil ve konuşma becerilerine odaklandığı görülmektedir. Eğitim programlarının sosyal beceriler üzerine yeterince odaklanmaması ve ayrıca öğretmenlerin de bu becerilerin öğretimine yeterince önem vermemesi gibi faktörlerin, eğitime başlama yaşından bağımsız olarak çocukların sosyal becerilerinin yetersiz olmasina yol açtığı söylenebilir.

Otizmli çocuklarla yapılan bir araştırmada kardeşe sahip olmanın otizmli çocukların sosyal becerilerini, özellikle sosyal etkileşimlerini artırabileceği belirtilmiştir (Knott ve diğ., 2007). Bu araştırmada ise çalışma grubunun sosyal becerilerinin kardeşe sahip olma değişkenine göre farklılaşmadığı görülmüş, bu bulgunun çalışma grubuna özgü bir özellik olabileceği gibi araştırma grubunun çoğunluğunun düşük işlevli çocuklardan oluşmasından da kaynaklanmış olabileceği düşünülmüştür. Düşük işlevli çocukların kardeşleriyle etkileşime girme sıklığının az olduğu (Kaminsky ve Dewey, 2001) ve bu durumun otizmli çocukların yeni sosyal beceriler öğrenme olasılıklarını azalttı̆̆ 1 da söylenebilir.

Türkiye'de yüksek işlevli çocuklar Rehberlik Araştırma Merkezleri (RAM) tarafindan genel eğitim sınıflarına yerleştirilmekte, bir başka deyişle devam edilen kurum otizmin derecesini yansıtmaktadır. Bu araştırmada genel eğitim okuluna devam eden çocuklar yüksek işlevli, özel eğitim okullarına devam edenler ise düşük işlevli çocuklar olarak gruplanmışlardır. Analiz sonuçları, yüksek işlevli çocukların sosyal karşılıklılık, sosyal katılım/kaçınma alt ölçek puanları ile OSBP-T toplam puanlarının, düşük işlevli çocukların puanlarından yüksek olduğunu göstermiştir. Zarar verici sosyal davranışlar alt ölçeğinde ise düşük işlevli çocukların yüksek işlevli çocuklardan daha yüksek puanlar aldıkları görülmüştür. Otizmli çocuklarda işlev düzeyinin artması ile diğer becerilerle birlikte sosyal becerilerin de artmas1 (Scheurmann ve Weber, 2002) nedeniyle toplam puan, sosyal karşı1ıklılık ve sosyal katılım/kaçınma puanlarındaki bu farklılaşmanın beklendiği söylenebilir. Genel eğitim sınıflarına devam eden otizmli çocukların sosyal davranışlarının incelendiği bir başka araştırmada yüksek işlevli çocukların, düşük işlevli çocuklara oranla daha fazla sosyal etkileşime 
girdiği belirtilmiştir (Bauminger, Schulman ve Agam, 2003). Bu araştırmada ise yüksek işlevli çocukların zarar verici sosyal davranışlar alt ölçeğinden aldıkları puanların düşük işlevli çocuklara benzer olduğu belirlenmiş; bu sonuçlar çocukların doğrudan olumsuz akran etkileşimlerine yol açan sosyal davranışlarının birbirine yakın olduğunu göstermiştir. Bellini ve Hopf (2007) OSBP'nin düşük işlevli otizmli çocuklara oranla yüksek işlevli çocukların sosyal becerilerini değerlendirmede daha geçerli bir araç olabileceğini belirtmişlerdir. $\mathrm{Bu}$ araştırmanın sonuçları da Bellini ve Hopf'un bulgularını destekler niteliktedir.

Otizmli çocukların tanılanma sürecinde Türkiye'de RAM'lar ve hastaneler tarafından otizmin tüm özelliklerini sergilemeyen ancak otizm spektrum bozukluğundaki diğer tanı gruplarının belirleyici özeliklerinden bazılarını gösterse de hiçbir kategoriye tam olarak uymayan çocuklara YGB veya YGB-BTT olarak tanı verilmektedir. Bu sebeple, çalışma grubunda yer alan çocuklar RAM'lar veya hastanelerde otizm tanısı almış çocuklar ile YGB tanısı almış çocuklar olarak ikiye ayrılmış ve iki grubun sosyal becerileri aldıkları tanıya göre karşılaştırılmıştır. Sosyal becerilerin tanıya göre farklılaşıp farklılaşmadığına bakıldığında, YGB tanılı çocukların sosyal karşı1ıklılık alt ölçeğinden aldıkları puanlar otizmli çocuklardan daha yüksek bulunurken; OSBP-T toplam puanları, sosyal katılım/kaçınma ve zarar verici sosyal davranışlar alt ölçeğinden aldıkları puanlar arasında ise anlamlı bir fark olmadığı görülmüştür. YGB tanılı çocukların yüksek puan aldıkları alt ölçek, olumlu sosyal davranışları tanımlayan maddeleri içermektedir. Alanyazında da otizmli çocukların iletişim ve sosyal becerilerdeki yetersizliklerinin YGB tanılı çocuklara göre daha belirgin ve daha fazla olduğu vurgulandığından (örn., Fodstad, Matson, Hess ve Neal, 2009) bu sonuçların beklendik olduğu söylenebilir.

Sonuç olarak, OSBP-T kullanılarak otizmli çocukların sosyal becerilerinin farklı değişkenler açısından değerlendirildiği bu çalışmada değerlendiren kişinin, otizmin derecesinin ve tanının ölçekten alınan puanlarda farklılaşmaya yol açtığı cinsiyet, yaş, eğitime başlama yaşı ve kardeşe sahip olmanın ise puanlarda farklılaşmaya yol açmadığı belirlenmiştir. Araştırma bulgularının başka çalışmalarla desteklenmesinin otizmli çocukların sosyal becerilerini etkileyen faktörlerin belirlenmesinde ve bu becerilerin geliştirilmesi için önlemler alınmasında kolaylık sağlayacağ düsşünülmektedir. Benzer şekilde uygulamacı ve öğretmenlerin otizmli çocuklara sosyal beceri öğretimi programı hazırlarken OSBP-T'yi kullanmaları, otizmli çocukların sosyal beceri yetersizliklerini temel alan müdahaleler geliştirmelerini ve müdahalelerin etkilerini değerlendirmelerini kolaylaştıracaktır. 


\section{KAYNAKLAR}

Amerikan Psikiyatri Birliği (2013). Ruhsal bozuklukların tanısal ve sayımsal elkitabl, Beşinci Baskı (DSM-5), Tanı Ölçütleri Başvuru Kitabı'ndan, Çev. Köroğlu, E., Ankara: Hekimler Yayın Birliği, Ankara.

Anderson, M. (2006). Autistic spectrum disorders. E. L. Heward (Ed.) Exceptional Children: An introduction to special education (pp. 260-297). New Jersey: Pearson Prentice Hall.

Balçık, B. (2010). Otizmli bireylere sosyal beceri öğretiminde sosyal öykülerin etkisinin incelenmesi. Yayınlanmamış yüksek lisans tezi. Abant İzzet Baysal Üniversitesi Sosyal Bilimler Enstitüsü, Bolu.

Baştürk, R. (2010). Bütün yönleriyle SPSS örnekli nonparametrik istatistiksel yöntemler. Ankara: Anı Yayıncilık.

Bauminger, N., Schulman, C., \& Agam, G. (2003). Peer interaction and loneliness in high-functioning children with autism. Journal of Autism and Developmental Disorders, 33(5), 489-507.

Bellini, S. (2006). The development of social anxiety in adolescents with autism spectrum disorders. Focus on Autism and Other Developmental Disabilities, 21(3), 138-145.

Bellini, S., \& Hopf, A. (2007). The development of the Autism Social Skills Profile: A preliminary analysis of psychometric properties. Focus on Autism and Other Developmental Disabilities, 22(2), 80-87.

Büyüköztürk, Ş., Kılıç Çakmak, E, Akgün, Ö.E., Karadeniz, Ş., \& Demirel, F. (2014). Bilimsel araştırma yöntemleri. Ankara: Pegem Akademi.

Constantino, J.N., Davis, S.A., Todd, R.D., Schindler, M.K., Gross, M.M., Brophy, S.L., et al. (2003). Validation of brief quantitative measure of autistic traits: Comparison of Social Responsiveness Scale with the Autistic Diagnostic Interview-Revised. Journal of Autism and Developmental Disorders, 33(4), $427-433$.

Day, H.M., Horner, R.H., \& O’Neill, R.E. (1994). Multiple functions of problem behaviors: Assessment and intervention. Journal of Applied Behavior Analysis, 27(2), 279-289.

Demir, Ş. (2009). Otizmli çocukların sosyal becerilerinin farkl değişkenler açısından değerlendirilmesi. Yayınlanmamış yüksek lisans tezi. Ankara Üniversitesi, Eğitim Bilimleri Enstitüsü, Ankara.

Fagan, J., \& Fantuzzo, J. W. (1999). Multirater congruence on the Social Skills Rating System: Mother, father, and teacher assessments of urban Head Start children's social competencies. Early Childhood Research Quarterly, 14(2), 229-242.

Fantuzzo, J., Coolahan, K., Mendez, J., McDermott, P., \& Sutton-Smith, B. (1998). Contextually-relevant validation of peer play constructs with African American Head Start children: Penn interactive peer play scale. Early Childhood Research Quarterly, 13, 411-431.

Fodstad, J.C., Matson, J.L., Hess, J., \& Neal, D. (2009). Social and communication behaviours in infants and toddlers with autism and pervasive developmental disorder-not otherwise specified. Developmental Neurorehabilitation, 12(3), $152-157$. 
Frankel, F., Myatt, R., \& Feinberg, D. (2007). Parent-assisted friendship training for children with autism spectrum disorders: Effects of psychotropic medication. Child Psychiatry and Human Development, 37, 337-346.

Green, G. (1996). Early behavioral intervention for autism: What does research tell us? In C. Maurice, G. Green, \& S.C. Luce (Eds.), Behavioral intervention for young children with autism (pp. 29-44). Austin, TX: Pro-Ed.

Gresham, F.M., \& Elliot, S.N. (1984). Assessment and classification of children's social skills: A review of methods and issues. School Psychology Review, 13, 292-301.

Gresham, F.M., \& Elliot, S.N. (1990). Social Skills Rating System. Circle Pines: American Guidance Services.

Glover-Gagnon, S., Nagle, R.J., \& Nickerson, A.B. (2007). Parent and teacher ratings of peer interactive play and social-emotional development of preschool children at risk. Journal of Early Intervention, 29(3), 228-242.

Harrower, J.K., \& Dunlap, G. (2001). Including children with autism in general education classrooms. Behavior Modification, 25, 762-784.

Hinshaw, S.P., Han, S., Erhardt, D., \& Huber, A. (1992). Internalizing and externalizing behavior problems in preschool children: Correspondence among parent and teacher ratings and behavior observations. Journal of Clinical Child Psychology, 21(2), 143-150.

Howlin, P., \& Goode, S. (1998). Outcome in adult life for people with autism and Asperger's syndrome. In F.R. Volkmar (Ed.), Autism and Pervasive Developmental Disorders (pp. 209-241). UK: Cambridge University Press.

http://orgm.meb.gov.tr. 15 Mart 2011 tarihinde erişilmiştir.

Kaminsky, L., \& Dewey, D. (2001). Sibling relationships of children with autism. Journal of Autism and Developmental Disorders, 31(4), 399-410.

Kanner, L. (1943). Autistic disturbances of affective contact. Nervous Child, 2, 217 250.

Klin, A., Saulnier, C.A., Sparrow, S.S., Cicchetti, D.V., Volkmar, F.R., \& Lord, C. (2007). Social and communication abilities and disabilities in higher functioning individuals with autism spectrum disorders: The Vineland and the ADOS. Journal of Autism and Developmental Disorders, 37, 748-759.

Knott, F., Lewis, C., \& Williams, T. (2007). Sibling interaction of children with autism: Development over 12 months. Journal of Autism and Developmental Disorders, 37, 1987-1995.

Koning, C., \& Magill-Evans, J. (2001). Social and language skills in adolescent boys with Asperger syndrome. Autism, 5, 23-36.

Macintosh, K., \& Dissanayake, C. (2006). Social skills and problem behaviours in school aged children with high-functioning autism and Asperger's disorder. Journal of Autism and Other Developmental Disorders, 36, 1065-1076.

Manz, P.H., Fantuzzo, J.W., \& McDermott, P.A. (1999). The parent version of the preschool social skills rating scale: An analysis of its use with low-income, ethnic minority children. School Psychology Review, 28(3), 493-504.

McKinnon, K., \& Krempa, J. (2002) Social skills solutions: A hands-on manual for teaching social skills to children with autism. New York: DRL Books. 
McLennan, J.D., Lord, C., \& Schopler, E. (1993). Sex differences in higher functioning people with autism. Journal of Autism and Developmental Disorders, 23(2), 217-227.

Merrell, K.W. (2001). Assessment of children's social skills: Recent developments, best practices, and new directions. Exceptionality, 9(1\&2), 3-18.

Milli Eğitim Bakanlığı (2000). Özel eğitim hakkında kanun hükmünde kararname ve özel eğitim hizmetleri yönetmeliği. Ankara: Milli Eğitim Basımevi.

Murray, D.S., Ruble, L.A., Willis, H., \& Molloy, C.A. (2009). Parent and teacher report of social skills in children with autism spectrum disorders. Language, Speech, and Hearing Services in Schools, 40, 109-115.

Ozonoff, S., \& Miller, J. N. (1995). Teaching theory of mind: A new approach to social skills training for individuals with autism. Journal of Autism and Developmental Disorders, 25(4), 415-433.

Randazzo, K.V.D., Landsverk, J., \& Ganger, W. (2003). Three informants' reports of child behavior: Parents, teacher, and foster parents. American Academy of Child and Adolescent Psychiatry, 42(11), 1343-1350.

Rogers, S.J. (1998). Empirically supported comprehensive treatments for young children with autism. Journal of Clinical Child Psychology, 27, 167-178.

Scheinkopf, S., \& Siegel, B. (1998). Home-based behavioral treatment for young autistic children. Journal of Autism and Developmental Disorders, 28(1), 15-23.

Scheuermann, B., \& Webber, J. (2002). Teaching does make a difference. Canada: Thomson Learning.

Skuse, D.H., Mandy, W.P.L., Steer, C., Miller, L., Goodman, R., Lawrence, K. et al. (2009). Social communication competence and functional adaptation in a general population of children: Preliminary evidence for gender-by verbal IQ differential risk. Journal of American Academy of Child and Adolescent Psychiatry, 48(2), 128-137.

Szatmari, P., Archer, L., Fisman, S., \& Streiner, D.L. (1994). Parent and teacher agreement in the assessment of pervasive developmental disorders. Journal of Autism and Developmental Disorders, 24(6), 703-717.

Volkmar, F.R., Szatmari, P., \& Sparrow, S.S. (1993). Sex differences in pervasive developmental disorders. Journal of Autism and Developmental Disorders, 23, 579-591.

Weiss, M.J., \& Harris, S.L. (2001). Reaching out, joining in. Teaching social skills to young children with autism. Bethesda, MD: Woodbine House.

Winsler, A., \& Wallace, G.L. (2002). Behavior problems and social skills in preschool children: Parent-teacher agreement and relations with classroom observations. Early Education and Development, 13(1), 41-58.

Yirmiya, N., \& Sigman, M.D. (1991). High-functioning individuals with autism: Diagnosis, empirical findings, and theoretical issues. Clinical Psychology Review, 11, 669-683. 
